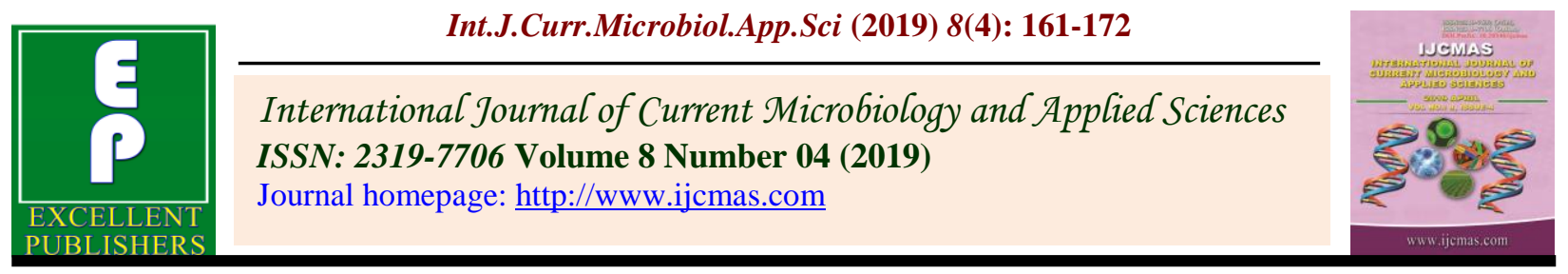

Original Research Article

https://doi.org/10.20546/ijcmas.2019.804.017

\title{
Comparison of Pre-harvest Forecast Models of Kharif Rice using Weather Parameters in Valsad District of Gujarat State
}

\author{
K.B. Banakara ${ }^{1}$, Amaresh $^{2}$, R. Manjula ${ }^{2}$ and H.R. Pandya ${ }^{1}$ \\ ${ }^{1}$ Department of Agricultural Statistics, Navsari Agricultural University, \\ Navsari, Gujarat - 396 450, India \\ ${ }^{2}$ Department of Agricultural Statistics, Applied Mathematics and Computer Sciences, \\ University of Agricultural Sciences, Bengaluru, Karnataka - 560 065, India \\ *Corresponding author
}

\begin{abstract}
A B S T R A C T
Keywords

Weather indices,

Discriminant

function, Logistic

Regression,

Forecast

Article Info

Accepted:

04 March 2019

Available Online:

10 April 2019

The growth of Indian economy mainly depends on agriculture sector as it accounts 18 percent of national GDP. Agriculture sector was one of the main area to impact by climate change. Pre-harvest forecast based on weather parameters plays very important role in developing countries. Rice is the most significant principal food in India which play fundamental role in day-to-day requisite of diet. In the current study statistical crop modeling was engaged to provide forecast in advance. In this paper discriminant function analysis and logistic regression techniques were used for estimating average rice yield for Valsad district in south Gujarat. The weather indices were developed for the years from 1990 to 2012 and utilized for model construction. The cross validation of the developed forecast model were confirmed using data of the years 2013 to 2016 . The study discovered that high value of $A d j . R^{2}$ was obtained in the model and which indicated that it was appropriate forecast model than other models. Based on the outcomes in Valsad district, Logistic regression analysis is found better as compared to Discriminant function for pre harvest forecasting of rice crop yield.
\end{abstract}

\section{Introduction}

Developing countries like India need to concentrate on Agriculture as it accounts 18 percent of national GDP. Rice is the most important staple food among principal crop cultivated in Asia. More than 90.00 per cent of the world's rice is grownup and consumed in Asia, where 60.00 per cent of the world's population lives. In the Gujarat state, rice occupies about 7.00 to 8.00 per cent of the gross cropped area of the state and accounts for around 14.00 per cent of the total food grain production. About 90.00 per cent of area under rice is confined to South and middle Gujarat (Singh et al., 2014). The pioneer work oncrop weather relationship study has been done by Fisher (1924) and Hendricks and Scholl (1943) at Indian Agricultural Statistic Research Institute, New Delhi. Later 
Agrawal et al., (1980) and Jain et al., (1980) modified this model by expressing effects of changes in weather parameters on yield in the particular week as second degree polynomial in respective correlation coefficients between yield and weather parameters. This model was further modified (Agrawal et al., 1986, 2011) by explaining the effects of changes in weather parameters on yield in particular week using correlation as weight using linear function. Some other investigators has developed different models for differenrt region and found significant results. They are Patel et al., (2007), Chauhan et al., (2009), Garde et al., (2012), Mahdi et al., (2013), Singh et al., (2014) and Pandey et al., (2015) studied the relationship of weather parameters and rice crop yield in different regions of world. Varmola et al., (2004), Agarwal et al., (2012) Sisodia et al., (2014) and Garde et al., (2015) developed forecast models for Wheat crop in different regions of India. Similarly, for pigeon pea Kumar et al., (1999) and Sarika et al., (2011), for Sugarcane Priya and Suresh and for Ground nut Dhekale et al., (2014) developed models. The development of forecast models for rice in Valsad district plays very important role, pre-harvest forecast needed in policy decision regarding export and import, food procurement and distribution, price policies and exercising several administrative measures for storage and marketing of agricultural commodities. Thus, the use of statistical models in forecasting food production and prices for agriculture hold great significance. Although no statistical model can help in forecasting the values exactly but by knowing even approximate values can help in formulating future plans.

\section{Materials and Methods}

The present study was carried out in the Valsad district of South Gujarat. Considering the specific objectives of the investigation, Kharif rice yield data were collected from the
Directorate of Economics and Statistics, Government of Gujarat, Gandhinagar, Gujarat from 1990 to 2016 . The study utilized weekly weather data which were collected from the Department of Agro meteorology, Navsari Agricultural University, Navsari. The maximum temperature $\left(X_{1}\right)$, minimum temperature $\left(X_{2}\right)$, Morning relative humidity $\left(X_{3}\right)$, Evening relative humidity $\left(X_{4}\right)$, and total rain fall $\left(X_{5}\right)$ considered for studying the effect on Kharif rice yield. The weekly weather data related to Kharif crop season starting from a first fortnight before sowing to last of reproductive stage were utilized for the development of statistical models. Therefore for the each year weather data, from MayJune $\left(23^{\text {rd }}\right.$ Standard Meteorological Week, SMW $)$ to October $\left(40^{\text {th }}\right.$ Standard Meteorological Week, SMW) were utilized for kharif crop.

\section{Developed weather indices using correlation coefficient as weight}

$$
Z_{i j}=\sum_{w=1}^{m} \sum_{j=0}^{1} r_{i w}^{j} X_{i w}
$$

Where,

$Z_{i j}$ is the developed weather indices of $j^{\text {th }}$ weight for $i^{\text {th }}$ weather variable

$r_{i w}$ is correlation coefficient of de-trended $Y$ with $w^{\text {th }}$ week of $i^{\text {th }}$ weather variable in $w^{\text {th }}$ week

$m$ is week of forecast

$i=1,2, \ldots, p$

$j=0,1$

$w=1,2, \ldots, \mathrm{m}$

$p$ 's are the number of parameters included in the model

\section{Statistical approaches}

In present investigation to analysis of data following different kind of statistical tools were utilized. 


\section{Discriminant function analysis}

Discriminant analysis is an appropriate statistical technique when the dependent variable is categorical and the independent variables are metric. It involves deriving a variate, a linear combination of two or more independent variables were discriminate best between prior defined groups. It is also an appropriate statistical technique for testing the hypothesis that the group means of a set of independent variables for two or more groups are equal.

Development of models based on two groups

\section{Method-1}

The model was developed using weather indices, five unweighted weather indices were used to extract discriminant scores usingdiscriminant function analysis. One discriminant score obtained for each year.The forecasting model was fitted taking the Kharifrice yield as the regressand and the onediscriminant score $\left(d s_{1}\right)$ \&trend $T$ as the regessors.

\section{Model-1}

$Y=\beta_{0}+\beta_{1} d s_{1}+\beta_{2} T+\varepsilon$

Where,

$Y$ is un-trended crop yield, $\beta i$ 's $(i=0,1,2)$ aremodel parameter, $d s_{1}$ is the discriminantscores, $T$ is the trend variable and $\epsilon$ is error term assumedto follow NID $\sim(0$, $\left.\sigma^{2}\right)$.

\section{Method-2}

The model was developed using weather indices, five weighted weather indices were used to extract discriminant scores using discriminant function analysis. One discriminant score was obtained.The forecasting model was fitted taking the Kharifrice yield as the regressand and the one discriminant score $\left(d s_{1}\right)$ and trend $T$ as the regessors.

Model-2

$Y=\beta_{0}+\beta_{1} d s_{1}+\beta_{2} T+\varepsilon$

Where,

$Y$ is un-trended crop yield, $\beta i$ 's $(i=0,1,2)$ aremodel parameter, $d s_{1}$ is the discriminantscores, $T$ is the trend variable and $\epsilon$ is error term assumedto follow NID $\sim\left(0, \sigma^{2}\right)$

\section{Method-3}

This model was same as developed by (Rai and Chandrahas, 2000). Total time starting from three weeks before transplanting up to the time of forecast (i.e., 14 weeks starting from $23^{\text {rd }}$ SMW) has been divided into five stages where each stages consists of different number of weeks. For each stage and each weather variable simple average of the weather data in the different weeks within the stage was obtained. This way for each phase five average weather variables were obtained. Taking these five average weather variables, phase wise discriminant function analysis was carried out and entire data on weather variables were converted to one discriminant score for each phase in each year. Thus, in all five scores were obtained for each year. Using these five discriminant scores and time trend as regressors and Kharif rice yield as regress and, model was fitted using regression technique.

\section{Model-3}

$Y=\beta_{0}+\sum_{l=1}^{1} \sum_{m=1}^{5} \beta_{l m} d s_{l m}+\beta_{11} T+\varepsilon$ 
Where,

$\beta_{0}=$ intercept of the model, $\beta_{l m}$ 's $(l=1, m=1$, $2, \ldots . ., 4)$ and $\beta_{11}$ are the regression coefficients, $d s_{\mathrm{lm}}$ is the $l^{\text {th }}$ discriminant score in $m^{\text {th }}$ phase, $T$ is the trend variable (year) and $\varepsilon$ is error NID $\sim\left(0, \sigma^{2}\right)$

\section{Development of models based on three groups}

\section{Method-4}

The model was developed using weather indices, five unweighted weather indices were used to extract discriminant scores usingdiscriminant function analysis.

Two discriminant scores were obtained.The forecasting model was fitted taking the Kharifrice yield as the regressand and the two sets of scores $\left(d s_{1}\right.$ and $\left.d s_{2}\right)$ and trend $T$ as the regessors.

\section{Model-4}

$Y=\beta_{0}+\beta_{1} d s_{1}+\beta_{2} d s_{2}+\beta_{3} T+\varepsilon$

Where,

$Y$ is un-trended crop yield, $\beta i$ 's $(i=0,1,2,3)$ aremodel parameter, $d s_{1}$ and $d s_{2}$ are two sets of discriminantscores, $T$ is the trend variable and $\epsilon$ is error term assumedto follow NID $\left(0, \sigma^{2}\right)$.

\section{Method-5}

The model was developed using weather indices, five weighted weather indices were used to extract discriminant scores usingdiscriminant function analysis. Two discriminant scores were obtained.The forecasting model was fitted taking the Kharifrice yield as the regressand and the two sets of scores $\left(d s_{1}\right.$ and $\left.d s_{2}\right)$ and trend $T$ as the regessors.

\section{Model-5}

$Y=\beta_{0}+\beta_{1} d s_{1}+\beta_{2} d s_{2}+\beta_{3} T+\varepsilon$

Where,

$Y$ is un-trended crop yield, $\beta i$ 's $(i=0,1,2,3)$ aremodel parameter, $d s_{1}$ and $d s_{2}$ are two sets of discriminantscores, $T$ is the trend variable and $\epsilon$ is error term assumedto follow NID $\left(0, \sigma^{2}\right)$.

\section{Method-6}

This model was same as developed by (Rai and Chandrahas, 2000). Total time starting from three weeks before transplanting up to the time of forecast (i.e., 14 weeks starting from $23^{\text {rd }} \mathrm{SMW}$ ) has been divided into five stages where each stages consists of different number of weeks. For each stage and each weather variable simple average of the weather data in the different weeks within the stage was obtained. This way for each phase five average weather variables were obtained. Taking these five average weather variables, phase wise discriminant function analysis was carried out and entire data on weather variables were converted to two discriminant scores for each phase in each year. Thus, in all ten scores were obtained for each year. Using these ten discriminant scores and time trend as regressors and Kharif rice yield as regressand, model was fitted using regression technique.

\section{Model-6}

$Y=\beta_{0}+\sum_{l=1}^{2} \sum_{m=1}^{5} \beta_{l m} d s_{l m}+\beta_{11} T+\varepsilon$

Where,

$\beta_{0}=$ intercept of the model, $\beta_{l m}$ 's $(l=1,2 ; m=$ $1,2, \ldots ., 4)$ and $\beta_{11}$ are the regression coefficients, $d s_{\operatorname{lm}}$ is the $l^{\text {th }}$ discriminant score in $m^{\text {th }}$ phase, $T$ is the trend variable (year) and $\varepsilon$ is error NID $\sim\left(0, \sigma^{2}\right)$. 


\section{Logistic regression}

Logistic regression is mathematical modelling approach that can be used to describe the relationship of several variables to a binary/dichotomous dependent variable. Cox (1958) and Walker and Duncan (1967) are pioneer to logistic regression.

Models were developed as discriminant function for two and three groups, here logistic probabilities were generated using ordinal logistic regression instead of discriminant scores. These logistic probabilities were utilized for the development of models. Another sixmodels were developed in this approach and the Models were named asModel-7 to Model-12 in sequence as in discriminant function analysis.

\section{Comparison and validation of models}

The comparisons and validation of models were done using following approaches.

\section{Forecast error (\%)}

The validation of the model using observed yield $\left(\mathrm{O}_{\mathrm{i}}\right)$ and forecasted yield $\left(\mathrm{E}_{\mathrm{i}}\right)$ was computed using below formula.

Forecast Error $=\left[\frac{O_{i}-E_{i}}{O_{i}}\right] \times 100$

\section{Coefficient of multiple determination (Adjusted $\mathbf{r}^{2}$ )}

The best fitted model among developed models were decided based on highest value of Adjusted $R^{2}$

$$
R_{a d j}^{2}=1-\frac{S S_{r e s} /(n-p)}{S S_{t} /(n-1)}
$$

Where, $s s_{\text {res }} /(n-p)$ is the residual mean square $s s_{t} /(n-1)$ is the total mean sum of square.

\section{Root Mean Squared Error (RMSE)}

The cross validation of the model were done using RMSE, for the year 2013 to 2016 using observed yield $\left(\mathrm{O}_{\mathrm{i}}\right)$ and forecasted yield $\left(\mathrm{E}_{\mathrm{i}}\right)$ was computed using below formula,

$R M S E=\left[\frac{1}{n} \sum_{i=1}^{n}\left(O_{i}-E_{i}\right)^{2}\right]^{1 / 2}$

\section{Results and Discussion}

The models were developed from $35^{\text {th }}$ Standard Meteorological Week (SMW) to $40^{\text {th }}$ Standard Meteorological Week (SMW) for all identified methods of model construction and best model was selected based on highest Adj. $R^{2}$. Models developed using two group discriminant function analysis were indicated in Table 1 and models developed using three group discriminant function analysis were indicated in Table 3. Table 5 and 7 were developed using two and three group ordinal logistic regression analysis respectively.

The Adj. $R^{2}$ values varies from 26.90 per cent to 64.30 per cent for two group discriminant function analysis which is presented in Table 1. Model-2 is considered as best fit for two group discriminant function analysis with highest Adj. $R^{2}$ value of 64.30 per cent. Similarly for three group discriminant function analysis Adj. $R^{2}$ varies from 33.30 per cent to 65.20 per cent which is presented in Table 3. Model-5 is considered as best fit with highest Adj. $R^{2}$ value of 65.20 per cent. Comparisons of models were made using forecast yield, forecast error and RMSE. Among the best fitted models, forecast error ranges from 5.37 to 25.21 in Model-2and 7.49 to 25.91 in Model-5 and RMSE of Model-2 is 
404.21 whichis lower than Model-5'sRMSE value of 421.14. Based on highest Adj. $R^{2}$ Model-5 was selected as best fit among discriminant function analysis models which utilizes maximum amount of data for analysis. Graphical representation of comparison of different discriminant function models was given in Figure 1 and 2. In logistic regression analysis, the Adj. $R^{2}$ value varies from 28.20 per cent to 68.10 per cent which is indicated in Table 5 and Model- 8 was selected as best fit for two group logistic regression analysis based on Adj. $R^{2}$ value.

Similarly for three groups Adj. $R^{2}$ varies from 39.10 per cent to 61.80 per cent as shown in Table 7 and the Model-11 was selected as best based on higher Adj. $R^{2}$ value (Table 19).

Table.1 Pre-harvest forecast models for two group discriminant function analysis

\begin{tabular}{|c|c|l|c|}
\hline SMW & $\begin{array}{c}\text { Model } \\
\text { Name }\end{array}$ & \multicolumn{1}{|c|}{ Model Equations } & Adj. $^{2}$ \\
\hline $\mathbf{3 8}$ & Model-1 & $Y=1918.52+5.64 T-81.62 d s_{1}{ }^{*}$ & $\mathbf{2 6 . 9 0}$ \\
\hline $\mathbf{4 0}$ & Model-2 & $Y=1896.34+7.49 T^{*}+101.99 d s_{1}^{*}$ & $\mathbf{6 4 . 3 0}$ \\
\hline $\mathbf{3 9}$ & Model-3 & $Y=1921.38+5.40 T-62.44 d s_{1}+23.77 d s_{2}-68.59 d s_{3}{ }^{*}$ & $\mathbf{3 4 . 9 0}$ \\
\hline
\end{tabular}

Table.2 Comparison of Pre-harvest forecast models for two group discriminant function analysis

\begin{tabular}{|c|c|c|c|c|c|c|c|}
\hline SMW & $\begin{array}{l}\text { Model } \\
\text { Name }\end{array}$ & Year & $\begin{array}{l}\text { Observed } \\
\text { yield }\end{array}$ & $\begin{array}{c}\text { Forecasted } \\
\text { Yield }\end{array}$ & $\begin{array}{c}\text { Forecast } \\
\text { Error }\end{array}$ & RMSE & $\operatorname{Adj} R^{2}$ \\
\hline \multirow[t]{4}{*}{38} & \multirow[t]{4}{*}{ Model-1 } & 2013 & 2157 & 2154 & 0.12 & \multirow[t]{4}{*}{468.20} & \multirow[t]{4}{*}{26.90} \\
\hline & & 2014 & 2479 & 2176 & 12.24 & & \\
\hline & & 2015 & 2423 & 2111 & 12.88 & & \\
\hline & & 2016 & 2888 & 2059 & 28.71 & & \\
\hline \multirow[t]{4}{*}{40} & \multirow[t]{4}{*}{ Model-2 } & 2013 & 2157 & 2041 & 5.37 & \multirow[t]{4}{*}{404.21} & \multirow[t]{4}{*}{64.30} \\
\hline & & 2014 & 2479 & 2225 & 10.25 & & \\
\hline & & 2015 & 2423 & 2209 & 8.83 & & \\
\hline & & 2016 & 2888 & 2160 & 25.21 & & \\
\hline \multirow[t]{4}{*}{39} & \multirow[t]{4}{*}{ Model-3 } & 2013 & 2157 & 2037 & 5.56 & \multirow[t]{4}{*}{467.10} & \multirow[t]{4}{*}{34.90} \\
\hline & & 2014 & 2479 & 2123 & 14.36 & & \\
\hline & & 2015 & 2423 & 2176 & 10.20 & & \\
\hline & & 2016 & 2888 & 2069 & 28.36 & & \\
\hline
\end{tabular}

Table.3 Pre-harvest forecast models for three group discriminant function analysis

\begin{tabular}{|l|c|l|l|}
\hline SMW & $\begin{array}{c}\text { Model } \\
\text { Name }\end{array}$ & \multicolumn{1}{|c|}{ Model Equations } & \multicolumn{1}{|c|}{ Adj. $\mathbf{R}^{2}$} \\
\hline $\mathbf{3 8}$ & Model-4 & $Y=1998.44-1.02 T-103.74 d s_{1} *+19.40 d s_{2}$ & $\mathbf{3 3 . 3 0}$ \\
\hline $\mathbf{4 0}$ & Model-5 & $Y=1929.39+4.73 T+99.20 d s_{1} *+14.27 d s_{2}$ & $\mathbf{6 5 . 2 0}$ \\
\hline $\mathbf{3 5}$ & Model-6 & $Y=1986.24+102.82 d s_{1}{ }^{*}$ & $\mathbf{3 9 . 0 0}$ \\
\hline
\end{tabular}


Table.4 Comparison of Pre-harvest forecast models for three group discriminant function analysis

\begin{tabular}{|c|c|c|c|c|c|c|c|}
\hline SMW & Model Name & Year & $\begin{array}{c}\text { Observed } \\
\text { yield }\end{array}$ & $\begin{array}{l}\text { Forecasted } \\
\text { Yield }\end{array}$ & $\begin{array}{c}\text { Forecast } \\
\text { Error }\end{array}$ & RMSE & $\operatorname{Adj} R^{2}$ \\
\hline \multirow[t]{4}{*}{38} & \multirow[t]{4}{*}{ Model-4 } & 2013 & 2157 & 2089 & 3.12 & \multirow[t]{4}{*}{433.45} & \multirow[t]{4}{*}{33.30} \\
\hline & & 2014 & 2479 & 2268 & 8.53 & & \\
\hline & & 2015 & 2423 & 2201 & 9.17 & & \\
\hline & & 2016 & 2888 & 2080 & 27.98 & & \\
\hline \multirow[t]{4}{*}{40} & \multirow[t]{4}{*}{ Model-5 } & 2013 & 2157 & 1956 & 9.32 & \multirow[t]{4}{*}{421.14} & \multirow[t]{4}{*}{65.20} \\
\hline & & 2014 & 2479 & 2206 & 11.03 & & \\
\hline & & 2015 & 2423 & 2242 & 7.49 & & \\
\hline & & 2016 & 2888 & 2138 & 25.95 & & \\
\hline \multirow[t]{4}{*}{40} & \multirow[t]{4}{*}{ Model-6 } & 2013 & 2157 & 1913 & 11.31 & \multirow[t]{4}{*}{668.35} & \multirow[t]{4}{*}{39.00} \\
\hline & & 2014 & 2479 & 1759 & 29.06 & & \\
\hline & & 2015 & 2423 & 1850 & 23.66 & & \\
\hline & & 2016 & 2888 & 1950 & 32.48 & & \\
\hline
\end{tabular}

Table.5 Pre-harvest forecast models for two group logistic regression analysis

\begin{tabular}{|c|c|l|c|}
\hline SMW & $\begin{array}{c}\text { Model } \\
\text { Name }\end{array}$ & \multicolumn{1}{|c|}{ Model Equations } & Adj. $\mathbf{R}^{2}$ \\
\hline $\mathbf{3 8}$ & Model-7 & $Y=2101.55+6.17 T-362.94 P s_{1}{ }^{*}$ & $\mathbf{2 8 . 2 0}$ \\
\hline $\mathbf{4 0}$ & Model-8 & $Y=2054.89+6.25 T-275.32 P s_{1}{ }^{*}$ & $\mathbf{6 8 . 1 0}$ \\
\hline $\mathbf{4 0}$ & Model-9 & $Y=2121.13+6.13 T-304.25 P s_{1}+265.88 P s_{2}-361.22 P s_{3}$ & $\mathbf{3 5 . 6 0}$ \\
\hline
\end{tabular}

Table.6 Comparison of Pre-harvest forecast models for two group logistic regression analysis

\begin{tabular}{|c|c|c|c|c|c|c|c|}
\hline $\begin{array}{l}\text { Model } \\
\text { Name }\end{array}$ & SMW & Year & $\begin{array}{l}\text { Observed } \\
\text { yield }\end{array}$ & $\begin{array}{c}\text { Forecasted } \\
\text { Yield }\end{array}$ & $\begin{array}{c}\text { Forecast } \\
\text { Error }\end{array}$ & RMSE & $\operatorname{Adj} R^{2}$ \\
\hline \multirow[t]{4}{*}{ Model-7 } & \multirow[t]{4}{*}{38} & 2013 & 2157 & 2170 & -0.63 & \multirow[t]{4}{*}{463.67} & \multirow[t]{4}{*}{28.20} \\
\hline & & 2014 & 2479 & 2190 & 11.67 & & \\
\hline & & 2015 & 2423 & 2121 & 12.48 & & \\
\hline & & 2016 & 2888 & 2060 & 28.66 & & \\
\hline \multirow[t]{4}{*}{ Model-8 } & \multirow[t]{4}{*}{40} & 2013 & 2157 & 1930 & 10.53 & \multirow[t]{4}{*}{455.47} & \multirow[t]{4}{*}{68.10} \\
\hline & & 2014 & 2479 & 1936 & 21.91 & & \\
\hline & & 2015 & 2423 & 2217 & 8.49 & & \\
\hline & & 2016 & 2888 & 2224 & 22.99 & & \\
\hline \multirow[t]{4}{*}{ Model-9 } & \multirow[t]{4}{*}{40} & 2013 & 2157 & 2059 & 4.53 & \multirow[t]{4}{*}{463.23} & \multirow[t]{4}{*}{35.60} \\
\hline & & 2014 & 2479 & 2126 & 14.23 & & \\
\hline & & 2015 & 2423 & 2163 & 10.72 & & \\
\hline & & 2016 & 2888 & 2077 & 28.07 & & \\
\hline
\end{tabular}


Table.7 Pre-harvest forecast models for three group logistic regression analysis

\begin{tabular}{|c|c|l|c|}
\hline SMW & $\begin{array}{c}\text { Model } \\
\text { Name }\end{array}$ & \multicolumn{1}{|c|}{ Model Equations } & Adj. $\mathbf{R}^{\mathbf{2}}$ \\
\hline $\mathbf{3 5}$ & Model-10 & $Y=2295.57-0.51 T-597.98 P s_{1} *-313.81 P s_{2}$ & $\mathbf{3 9 . 1 0}$ \\
\hline $\mathbf{4 0}$ & Model-11 & $Y=2020.45+7.27 T-289.12 P s_{1} *-68.66 P s_{2}$ & $\mathbf{6 1 . 8 0}$ \\
\hline 39 & Model-12 & $Y=2211.16-440.94 P s_{1} *-205.78 P s_{5} *$ & $\mathbf{5 3 . 3 0}$ \\
\hline
\end{tabular}

Table.8 Comparison of Pre-harvest forecast models for two group logistic regression analysis

\begin{tabular}{|c|c|c|c|c|c|c|c|}
\hline $\begin{array}{l}\text { Model } \\
\text { Name }\end{array}$ & $\begin{array}{l}\text { SMW } \\
\text { No. }\end{array}$ & Year & $\begin{array}{l}\text { Observed } \\
\text { yield }\end{array}$ & $\begin{array}{c}\text { Forecasted } \\
\text { Yield }\end{array}$ & $\begin{array}{c}\text { Forecast } \\
\text { Error }\end{array}$ & RMSE & $\operatorname{Adj} \mathbf{R}^{2}$ \\
\hline \multirow[t]{4}{*}{ Model-10 } & \multirow[t]{4}{*}{35} & 2013 & 2157 & 2095 & 2.85 & \multirow[t]{4}{*}{466.13} & \multirow[t]{4}{*}{39.10} \\
\hline & & 2014 & 2479 & 2145 & 13.49 & & \\
\hline & & 2015 & 2423 & 2140 & 11.70 & & \\
\hline & & 2016 & 2888 & 2067 & 28.41 & & \\
\hline \multirow[t]{4}{*}{ Model-11 } & \multirow[t]{4}{*}{40} & 2013 & 2157 & 1921 & 10.94 & \multirow[t]{4}{*}{532.73} & \multirow[t]{4}{*}{61.80} \\
\hline & & 2014 & 2479 & 2033 & 17.98 & & \\
\hline & & 2015 & 2423 & 2037 & 15.93 & & \\
\hline & & 2016 & 2888 & 2032 & 29.63 & & \\
\hline \multirow[t]{4}{*}{ Model-12 } & \multirow[t]{4}{*}{39} & 2013 & 2157 & 1986 & 7.90 & \multirow[t]{4}{*}{446.52} & \multirow[t]{4}{*}{53.30} \\
\hline & & 2014 & 2479 & 2122 & 14.41 & & \\
\hline & & 2015 & 2423 & 2139 & 11.71 & & \\
\hline & & 2016 & 2888 & 2139 & 25.92 & & \\
\hline
\end{tabular}

Table.9 Comparison of Pre-harvest forecast models for discriminant function and logistic regression analysis

\begin{tabular}{|c|c|c|c|c|c|c|c|}
\hline $\begin{array}{l}\text { Model } \\
\text { Name }\end{array}$ & SMW & Year & $\begin{array}{l}\text { Observed } \\
\text { yield }\end{array}$ & $\begin{array}{c}\text { Forecasted } \\
\text { Yield }\end{array}$ & $\begin{array}{c}\text { Forecast } \\
\text { Error }\end{array}$ & RMSE & $\operatorname{Adj} R^{2}$ \\
\hline \multirow[t]{4}{*}{ Model-5 } & \multirow[t]{4}{*}{40} & 2013 & 2157 & 1956 & 9.32 & \multirow[t]{4}{*}{421.14} & \multirow[t]{4}{*}{65.20} \\
\hline & & 2014 & 2479 & 2206 & 11.03 & & \\
\hline & & 2015 & 2423 & 2242 & 7.49 & & \\
\hline & & 2016 & 2888 & 2138 & 25.95 & & \\
\hline \multirow[t]{4}{*}{ Model-8 } & \multirow[t]{4}{*}{40} & 2013 & 2157 & 1930 & 10.53 & \multirow[t]{4}{*}{455.47} & \multirow[t]{4}{*}{68.10} \\
\hline & & 2014 & 2479 & 1936 & 21.91 & & \\
\hline & & 2015 & 2423 & 2217 & 8.49 & & \\
\hline & & 2016 & 2888 & 2224 & 22.99 & & \\
\hline
\end{tabular}


Fig.1 Graphical representation of two group discriminant function analysis

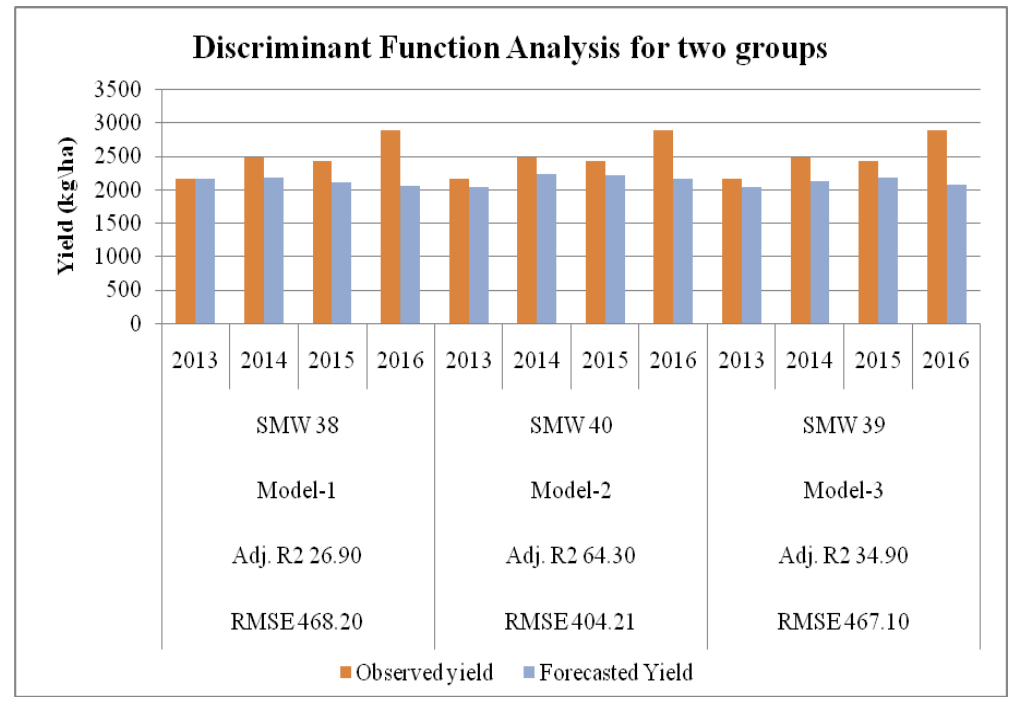

Fig.2 Graphical representation of three group discriminant function analysis

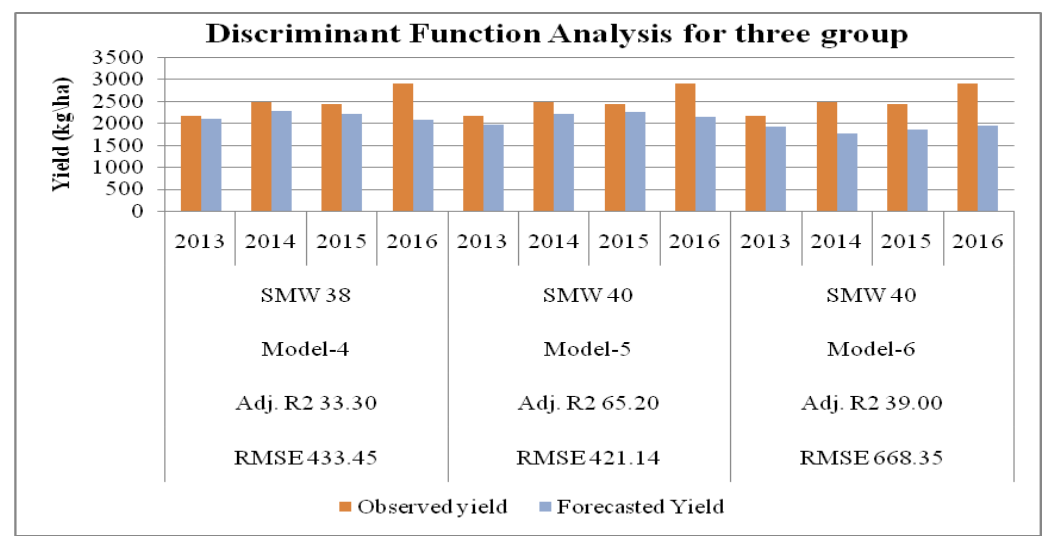

Fig.3 Graphical representation of two group Logistic regression analysis

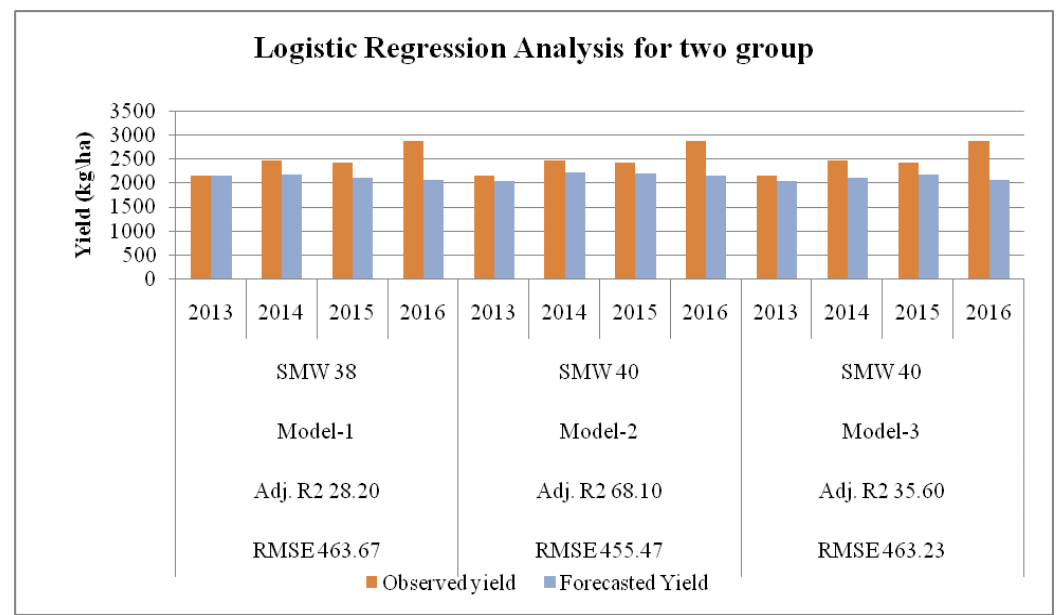


Fig.4 Graphical representation of the group Logistic regression analysis

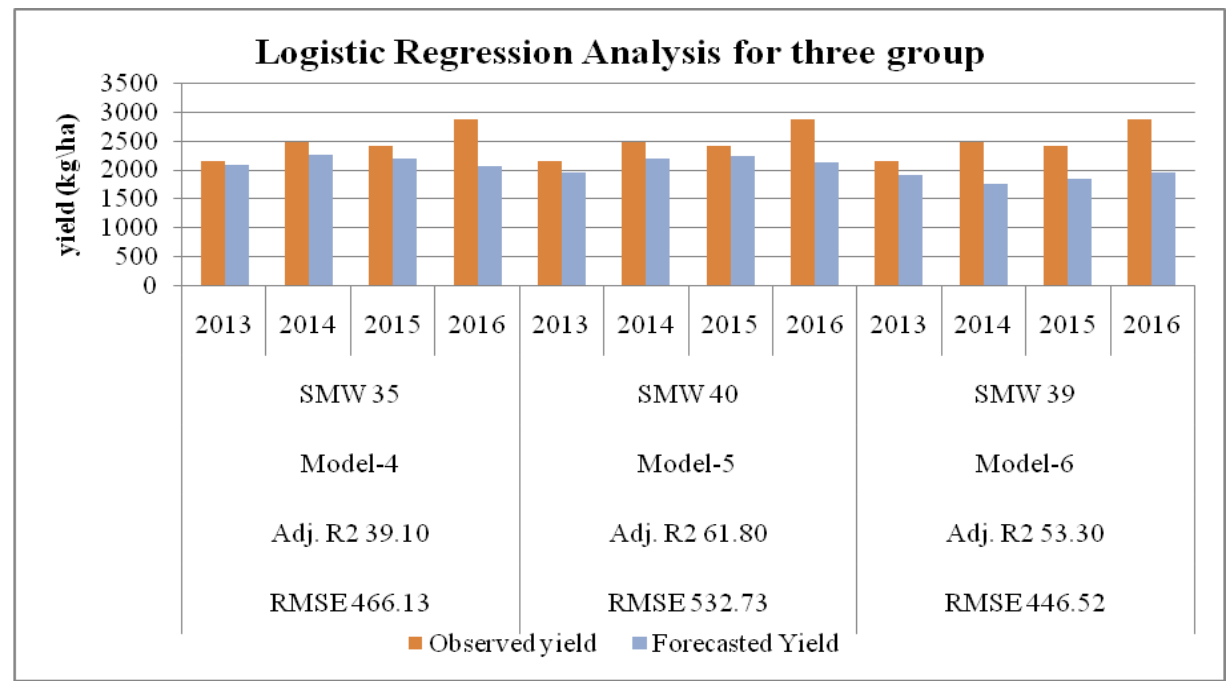

Fig.5 Graphical representation comparison of discriminant function and logistic regression

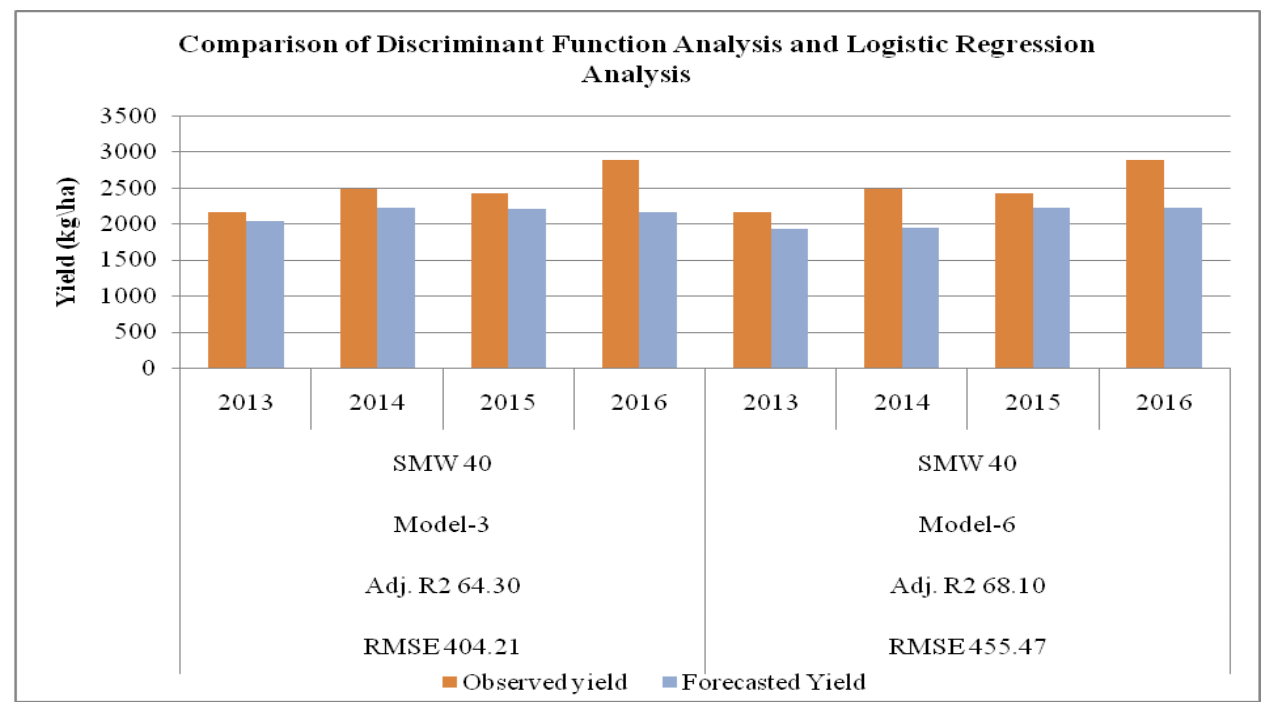

Comparisons of models were made using forecast yield, forecast error and RMSE. Among the best models, the forecast error ranges from 8.49 to 22.99 in Model-8 and 10.94 to 29.63 in Model-11. The RMSE value for Model-8 is 455.47 which is lower than Model-11's RMSE value of 532.73. Model-8 is selected as best fit model among logistic regression analysis models based on highest Adj. $R^{2}$ with lower RMSE value of 455.47 . Graphical representation of comparison of different logistic regression models was given in Figure 3 and 4. The comparison of discriminant function analysis and logistic regression analysis were made using Adj. $R^{2}$, forecast error and RMSE criteria.Logistic regression analysis was found better as compared to Discriminant function in terms of highest Adj. $R^{2}(68.10)$ and slightly higher RMSE (455.47) as compared to Model-5's RMSE value of 421.14 and forecast error ranges from 8.49-22.99 which is presented in Table 9. Graphical representation of comparison of discriminant function and 
logistic regression models was given in Figure 5.

In conclusion, using the forecast techniques like discriminant function analysis and logistic regression, pre-harvest estimates of rice crop yield for Valsad district could be computed successfully before five weeks of actual harvest. Kumari et al., (2016) and Sudesh et al., (2016) were developed logistic regression with traditional model and found that logistic regression was superior to traditional methods. It can be concluded from the results that, there is a wide scope for using alternative approaches to develop predictors that could be used in forecasting models for reliable and dependable forecast. Therefore, it is important to develop pre-harvest forecasting models and these forecasts have significant value in agricultural planning and policy making. This methodology can be applicable in many crops viz. rice, pulses, oil seeds, sugarcane etc.

\section{References}

Agrawal, R., Jain R. C and Jha M. P. 1980. Modes for studying rice-weather relationship. MAUSAM. 37(1): 67-70.

Agrawal, R., Chandrahas and Aditya, K. 2012. Use of discriminant function analysis for forecasting crop yield. MAUSAM. 63(3): 455-458.

Chauhan, V. S., Shekh, A. M., Dixit, S. K., Mishra, A. P. and Kumar, S. 2009. Yield prediction model of rice in Bulsar district of Gujarat. Journal of Agrometeorology. 11(2): 162-168.

Dhekale, B. S., Mahdi, S and Sawant, P. K. 2014. Forecast models for groundnut using meteorological variables in Kolhapur, Maharashtra. Journal of Agrometeorolog. 16(2): 238-239.

Fisher, R. A.1924.The influence of rainfall on yield of wheat at Rothamsted. Philosophical Transaction of Royal
Society of London. Series B.213: 89142.

Garde, Y. A., Dhekale, B. S and Singh, S.2015.Different approaches on pre harvest forecasting of wheat yield. Journal of Applied and Natural Science. 7(2): $839-843$.

Garde, Y. A., Shukla, A. Kand Singh, S. 2012. Pre-harvest forecasting of rice yield using weather indices in Pantnagar. International Journal of Agricultural Statistical Science.8(1): 233-241.

Kumar, R. Gupta, B. R. D., Athiyaman, B., Singh, K. K and Shukla, R. K. 1999. Stepwise regression technique to predict Pigeon pea yield in Varanasi district. Journal of Agrometeorology. 1(2): 183-186.

Mahdi,S. S., Lotus, S., Singh, G., Ahmad, L., Singh, K. N., Dar, L. A and Bhat, A. 2013. Forecast of rice (Oryza sativa L.) yield based on climatic parameters in Srinagar district of Kashmir Valley. Journal of Agrometeorology. 15(1): 8990.

Pandey, K. K., Rai, V. N., Sisodia, B. V. S and Singh, S. K. 2015.Effect of Weather Variables on Rice Crop in Eastern Uttar Pradesh. India. Plant Archives.15(1): 575-579.

Patel, G. B., Vaishnav, P. R., Patel, J. S and Dixit, S. K. 2007. Pre-harvest forecasting of rice (Oryza sativa L.) yield based on weather variables and technological trend. Journal of Agrometeorology. 9(2): 167-173.

Priya, S. R. K and Suresh, K. K. 2009.A study on pre-harvest forecast of sugarcane yield using climatic variables. Statistics and Applications.7\&8 (1\&2): 1-8.

Sarika., Iquebal, M. A and Chattopadhyay. 2011. Modelling and forecasting of pigeonpea (Cajanus cajan) production using autoregressive integrated moving average methodology. Indian Journal of 
Agricultural Sciences.81(6): 520-523.

Singh, N., Dikshit, A. K., Reddy, B. S and Kuthe, S. B. 2014. Instability in rice production in Gujarat: A decomposition analysis. Asian Journal of Economics and Empirical Research. 1: 6-9.

Singh, R. S., Patel, C., Yadav, M. K and Singh, K. K. 2014.Yield forecasting of rice and wheat crops for eastern Uttar Pradesh.Journal of Agrometeorology.16(2): 199-202.
Sisodia, B. V. S., Yadav, R. R., Kumar, S And Sharma, M. K. 2014. Forecasting of pre-harvest crop yield using discriminant function analysis of meteorological parameters. Journal of Agrometeorology. 16(1): 121-125.

Varmora, S. L., Dixit, S. K., Patel, J. S and Bhatt, H. M. 2004. Forecasting of wheat yield on the basis of weather variables. Journal of Agrometeorology. 6(2): 223228.

\section{How to cite this article:}

Banakara, K.B., Amaresh, R. Manjula and Pandya, H.R. 2019. Comparison of Pre-harvest Forecast Models of Kharif Rice using Weather Parameters in Valsad District of Gujarat State. Int.J.Curr.Microbiol.App.Sci. 8(04): 161-172. doi: https://doi.org/10.20546/ijcmas.2019.804.017 